\title{
Faktor-faktor yang Mendukung dan Menghambat Dilakukannya Versi Luar pada Kehamilan dengan Presentasi Bokong di Yogyakarta
}

\author{
I Made Pariartha ${ }^{1}$, Rukmono Siswishanto ${ }^{2}$, Nuring Pangastuti ${ }^{3}$ \\ 1,2,3 Departemen Obstetri dan Ginekologi \\ Fakultas Kedokteran, Kesehatan Masyarakat dan Keperawatan \\ Universitas Gadjah Mada \\ Korespondensi: obsgin.juli2015@gmail.com
}

Submisi: 17 September 2020; Revisi: 20 September 2020; Penerimaan: 15 Oktober 2020

\begin{abstract}
Background: Guidelines recommend that external cephalic version (ECV) should be offer to all women with fetus in breech presentation at term. Many literature show external cephalic version can lowering c-section rate caused by breech presentation.

Objective: To explore the determinants (barriers and facilitators) affecting obstetricians and gynaecologists to do external cephalic version at Yogyakarta.

Method: Explanatory mixed methods design with quantitative-qualitative model. Survey with validated questionnaire and in-depth interview with semi-structured question was done January 2019 until August 2019.

Result and Discussion: 72 respondents (83.7\%) was responded to questionnaire and in-depth interview was done to 12 respondents. Adherence to ECV guideline was varied: counselling (20.8\%), advising for ECV (15.3\%), and arranged for ECV to for (almost) all their clients (16.6\%). Although $76.4 \%$ of respondents considered ECV to be an effective treatment for preventing caesarean childbirth, only $18.1 \%$ respondents agreed that every client with breech presentation should undergo ECV. Self-efficacy was the most important determinant influencing adherence. In-depth interview shows several determinants to performed or did not performed ECV: skill of clinicians, guideline for ECV, facility to emergency c-section, ECV characteristic, cost, other methods for breech presentation, perception about ECV in lowering c-section rate, perceived ECV risk and patient preferences.

Conclusion: Most respondents agreed that ECV was effective intervention to reduce caesarean childbirth, but adherence to counselling, advising and arranging ECV for clients still very low. Several determinants influenced obstetrician and gynaecologists to perform or did not perform ECV.
\end{abstract}

Keywords: External cephalic version; breech presentation; determinants

\begin{abstract}
ABSTRAK
Latar Belakang: Panduan merekomendasikan versi luar sebagai manajemen kehamilan dengan presentasi bokong sebaiknya ditawarkan pada setiap klien dengan kehamilan presentasi bokong cukup bulan. Banyak literatur menunjukkan peran versi luar menurunkan angka bedah sesar karena presentasi bokong.

Tujuan: Mengetahui determinan (faktor-faktor yang mendukung dan menghambat) dilakukannya versi luar oleh Dokter SpOG di Yogyakarta.

Metode: Penelitian campuran (explanatory mixed methods design) dengan model kuantitatif-kualitatif. Survei dengan kuesioner tervalidasi dan wawancara mendalam dengan daftar pertanyaan terstruktur yang dilakukan Bulan Januari 2019 sampai dengan Agustus 2019.

Hasil dan Pembahasan: 72 Dokter SpOG (83.7\%) mengisi kuesioner secara lengkap. Wawancara mendalam dilakukan pada 10 Dokter SpOG yang melakukan maupun tidak melakukan versi luar. Kepatuhan terhadap panduan versi luar bervariasi: mengkonseling (20.8\%), meyakinkan (15.3\%) dan mengupayakan (16.6\%) pada lebih dari sebagian besar pasien. Meskipun 76.4\% Dokter SpOG setuju bahwa versi luar merupakan terapi yang baik untuk menurunkan angka bedah sesar karena presentasi bokong, namun hanya 18.1\% Dokter SpOG yang setuju setiap pasien dengan presentasi bokong sebaiknya menjalani versi luar. Efikasi diri merupakan determinan paling penting yang mempengaruhi melakukan versi luar. Wawancara mendalam menunjukkan ada beberapa determinan yang menentukan dalam melakukan atau tidak melakukan versi luar: keterampilan, adanya panduan versi luar, fasilitas seksio sesarea emergensi, karakteristik versi luar, pembiayaan, pilihan metode persalinan presbo lain, persepsi versi luar dalam menurunkan angka seksio sesarea, risiko versi luar dan pilihan pasien.

Kesimpulan: Sebagian besar responden setuju bahwa versi luar merupakan tindakan yang sesuai untuk menurunkan angka bedah sesar karena presentasi bokong, namun kepatuhan dalam tiga aspek konseling, meyakinkan dan mengupayakan versi luar untuk klien dengan kehamilan presentasi bokong sangat rendah.
\end{abstract}

Kata kunci: versi luar; presentasi bokong; determinan 


\section{PENDAHULUAN}

Presentasi bokong terjadi kira-kira 3-4\% pada kehamilan cukup bulan. ${ }^{1}$ Metode persalinan yang direkomendasikan masih menjadi berdebatan, secara seksio sesarea atau vaginal terencana. Penelitian Term Birth Trial (TBT) menunjukkan tidak terdapat perbedaan mortalitas perinatal antara kedua metode persalinan, namun terdapat perbedaan bermakna pada morbiditas jangka pendek yang serius pada persalinan secara vaginal dibandingkan dengan seksio sesarea, yaitu $0.4 \%$ berbanding $5.1 \% .{ }^{1}$ Hasil penelitian ini menyebabkan angka seksio sesarea meningkat tajam. Sebaliknya, pada penelitian PREMODA menunjukkan tidak terdapat perbedaan yang bermakna antara mortalitas perinatal $(0.08 \%$ berbanding $0.15 \%)$ atau morbiditas perinatal yang serius $(1.6 \%$ berbanding $1.45 \%$ ) antara metode persalinan vaginal terencana dan seksio sesarea. ${ }^{2}$

Salah satu cara untuk menurunkan angka seksio sesarea adalah menurunkan angka presentasi bokong pada kehamilan cukup bulan. ${ }^{3}$ Peningkatan angka seksio sesarea mempunyai beberapa kerugian antara lain: peningkatan morbiditas ibu, admisi di RS yang lebih lama, dan komplikasi pada kehamilan selanjutnya (peningkatan risiko implantasi plasenta yang tidak normal, ruptur uteri, dan akibatnya kematian janin). ${ }^{4}$ Sebagian besar panduan merekomendasikan dilakukan versi luar (external cephalic version) untuk merubah presentasi bokong menjadi presentasi kepala pada kandidat dan usia kehamilan yang sesuai. ${ }^{5-8}$ Tindakan ini dapat ditawarkan pada usia kehamilan 36 minggu pada nulipara dan 37 minggu pada multipara. ${ }^{5}$

Beberapa penelitian menyimpulkan versi luar merupakan prosedur yang aman dan dapat menurunkan angka seksio sesarea karena presentasi bokong dan menurunkan angka seksio sesarea dalam persalinan pada usaha persalinan bokong secara vaginal. ${ }^{9,10}$ Walaupun direkomendasikan di berbagai panduan, ternyata tidak semua klinisi menerapkan rekomendasi versi luar. Di Belanda, lima persen klinisi tidak pernah melakukan versi luar sama sekali. ${ }^{11}$ Jumlah wanita hamil di Inggris dan Amerika yang memenuhi syarat namun tidak ditawarkan versi luar berkisar antara $4 \%$ sampai dengan 33\%.6 Jumlah wanita di Israel yang berminat untuk melakukan versi luar menurun dari $54 \%$ menjadi hanya $24 \% .^{12}$

Untuk keberhasilan pelaksanaan versi luar, diperlukan kesediaan dari pasien dan penyedia layanan kesehatan (dokter dan bidan). ${ }^{13}$ Terdapat berbagai faktor yang menghambat dan mendukung pelaksanaan versi luar, yang dapat muncul dari penyedia layanan kesehatan dan pasien. ${ }^{11}$ Dalam melakukan versi luar, ada tiga langkah yang harus dilakukan. Pertama konseling klien yang memenuhi syarat untuk dilakukan versi luar, kemudian menawarkan dan meyakinkan klien untuk memilih versi luar. Terakhir, mengupayakan versi luar baik melakukan sendiri atau merujuk ke teman sejawat yang lebih ahli. Penelitian ini bertujuan untuk mengetahui faktor-faktor yang mendukung dan menghambat dilakukannya versi luar pada Dokter Spesialis Obstetri dan Ginekologi.

\section{METODE}

Rancangan penelitian ini adalah penelitian metode campuran (explanatory mixed methods design) dengan pendekatan kuantitatif-kualitatif. Untuk fase kuantitatif dilakukan dengan menyebarkan kuesioner ke Dokter Spesialis Obstetri dan Ginekologi yang praktik di Yogyakarta. Pada fase kualitatif dilakukan wawancara mendalam kepada 12 Dokter SpOG, baik yang melakukan dan tidak melakukan versi luar dengan jumlah responden masing-masing enam Dokter SpOG.

Penelitian ini menggunakan kuesioner dari penelitian sebelumnya di Belanda. ${ }^{14}$ Kuesioner ini diterjemahkan ke dalam Bahasa Indonesia dengan forward and backward translation. Sebelumnya dilakukan uji validitas dan reliabilitas. Hasil pengujian menunjukkan kuesioner ini mempunyai validitas dan reliabilitas yang baik, dengan Cronbach's alpha 0.924. Kuesioner ini mengukur kepatuhan terhadap tiga aspek pelaksanaan versi luar yang terdiri dari lima segi, yaitu: perilaku terhadap versi luar (10 butir); kewajiban sebagai profesional (8 butir); hasil yang diharapkan (4 butir); kepercayaan diri/selfefficacy (4 butir); kondisi prasyarat keberhasilan versi luar (15 butir) ditambah dengan tingkat kepatuhan secara mandiri (self-reported level of adherence). 
Untuk keseluruhan butir penelitian, digunakan skala likert dengan lima nilai, dari "sangat setuju" sampai dengan "sangat tidak setuju", kecuali untuk kepercayaan diri/self-efficacy (skala 4 nilai, dari "merasa sangat mampu untuk melakukan" sampai dengan "merasa sangat tidak mampu untuk melakukan"). Tingkat kepatuhan diukur pada tingkat tiga rekomendasi kunci pada pelaksanaan versi luar: mengkonseling, menawarkan/meyakinkan dan melakukan versi luar. Responden ditanyakan berapa pasien yang mereka konseling, tawarkan/yakinkan dan lakukan versi luar (skala likert 7 nilai, dari "tidak sama sekali" sampai dengan "semua"). Tiga butir ini digunakan sebagai ukuran-ukuran luaran (outcome measures) dalam analisis data. Berbagai variabel latar belakang yang relevan juga dinilai. Wawancara mendalam dilakukan dengan panduan wawancara dengan pertanyaan terstruktur sebagian. Sebelum digunakan panduan ini didiskusikan dulu dengan ahli penelitian kualitatif.

\section{HASIL DAN PEMBAHASAN}

Penelitian berlangsung dari Bulan Januari 2019 sampai dengan Bulan Agustus 2019. Dari 86 kuesioner yang disebar, 72 responden (83.7\%) bersedia dan mengisi kuesioner secara lengkap. Wawancara mendalam dilakukan kepada 12 orang Dokter SpOG baik yang melakukan maupun tidak melakukan versi luar. Karakteristik subjek penelitian menurut jenis kelamin, 39 responden (54.17\%) berjenis kelamin laki-laki dan 33 responden (45.83\%) berjenis kelamin perempuan. Untuk umur, 50 responden (69.44\%) berumur $\leq 50$ tahun dan 22 responden $(30.56 \%)$ berumur $>50$ tahun.

Untuk lama praktek sebagai Dokter SpOG, 36 responden (50.00\%) lama praktik kurang dari 10 tahun dan 36 responden $(50.00 \%)$ lama praktik $\geq 10$ tahun. Untuk pernah tidaknya melakukan versi luar, 27 responden (37.50\%) pernah melakukan versi luar dan 45 responden (62.50\%) tidak pernah melakukan versi luar. Pada responden yang tidak pernah melakukan versi luar ada beberapa alasan yang menyebabkan: $29.21 \%$ karena terlalu berisiko, $13.48 \%$ karena merasa kurang kompeten, 6.74\% karena tidak percaya diri, $29.21 \%$ karena tidak mendapatkan pelatihan memadai sebelumnya, dan $21.35 \%$ tidak pernah melakukan sebelumnya. Pada responden yang melakukan versi luar, delapan responden (29.63\%) melakukan pada usia kehamilan $\leq 34$ minggu. Sembilan belas responden (70.37\%) melakukan pada usia kehamilan >34 minggu.

Empat puluh dua responden (58.33\%) tidak percaya diri dalam melakukan versi luar dan 30 responden (41.67\%) percaya diri dalam melakukan versi luar. Untuk latihan keterampilan dalam melakukan versi luar selama residensi, 22 responden $(30.56 \%)$ merasa dibekali keterampilan yang memadai untuk melakukan versi luar selama residensi, sedangkan 50 responden (69.44\%) merasa tidak dibekali keterampilan yang cukup. Untuk jenis rumah sakit, 43 responden (59.72\%) bekerja di RS Pemerintah dan 29 responden (40.28\%) bekerja di RS Non Pemerintah. Untuk tipe rumah sakit, 37 responden (51.39\%) bekerja di RS Pendidikan dan 35 responden (48.61\%) bekerja di RS Non Pendidikan. Persetujuan responden terhadap seluruh butir kuesioner ditampilkan dalam lampiran 1.

\section{Sikap Terhadap Versi Luar}

Untuk analisis butir dimensi sikap terhadap versi luar, lebih dari $70 \%$ responden setuju pada butir: setiap klien dengan presentasi bokong sebaiknya diberikan konseling tentang versi luar (76.4\%), pengalaman klinis profesional mengarah pada keputusan untuk menawarkan versi luar kepada klien (79.1\%), versi luar merupakan terapi yang baik untuk menurunkan angka bedah sesar karena presentasi bokong (76.4\%), dan pengetahuan terhadap panduan (guideline) versi luar meningkatkan konseling versi luar (90.3\%).

Persetujuan responden terhadap pernyataan: Selama konseling harus dijelaskan bahwa versi luar merupakan pilihan terbaik untuk klien sangat rendah (30.6\%). Hanya $18.1 \%$ responden yang setuju pada pernyataan: Setiap klien dengan presentasi bokong sebaiknya menjalani versi luar. Pernyataan setiap klien yang gagal versi luar sebaiknya ditawarkan upaya yang kedua disetujui oleh $47.2 \%$ responden. Sedangkan pernyataan pemberian relaksan uterus sebaiknya ditawarkan ke semua klien disetujui oleh $47.2 \%$ responden. 


\section{Orientasi Tugas}

Hanya satu butir pernyataan yang disetujui oleh lebih dari $70 \%$ responden, yaitu pada butir: Para spesialis obstetri dan ginekologi bertugas memutuskan kontraindikasi versi luar (94.5\%). Hanya $44.5 \%$ responden yang setuju pada butir: Saya bertanggung jawab untuk meyakinkan setiap klien untuk memilih versi luar. Sebesar $68.1 \%$ responden setuju pada butir: Saya bertanggung jawab untuk memberikan konseling versi luar kepada setiap klien. Untuk butir pernyataan Saya bertanggung jawab mendiskusikan alasan jika ada teman sejawat yang tidak menawarkan versi luar hanya disetujui $51.4 \%$ responden.

\section{Hasil yang Diharapkan}

Untuk analisis dimensi hasil yang diharapkan, $55.6 \%$ responden setuju bahwa para klien lebih puas jika versi luar selalu ditawarkan. Sebagian besar responden (>70\%) setuju pada butir pernyataan: kebijakan yang jelas meningkatkan upaya versi luar (76.4\%), dan melakukan versi luar meningkatkan jumlah presentasi kepala saat persalinan (73.6\%). Sebesar 68\% responden setuju bahwa konseling meningkatkan jumlah klien yang memilih versi luar.

\section{Prasyarat Keberhasilan Versi Luar}

Sebagian besar responden (>80\%) setuju pada butir pernyataan: konseling sebaiknya berisi semua informasi tentang persalinan presentasi bokong mencakup persalinan secara vaginal dan bedah sesar (91.7\%), pencatatan kasus-kasus versi luar pada database obstetri nasional diperlukan untuk evaluasi yang baik (86.1\%), dan butir pernyataan: Jika perujuk mempunyai persepsi yang lebih baik tentang keahlian dan tingkat keberhasilan para spesialis obsgin, lebih banyak wanita yang dirujuk untuk versi luar (83.4\%).

Sebagian kecil responden setuju pada butir: versi luar aman dilakukan di luar RS, di bawah prasyarat perjanjian yang baik dengan RS jika terjadi komplikasi (26.4\%), insentif keuangan khusus diperlukan untuk konseling (48.6\%), jika versi luar hanya boleh di RS, jumlah praktik versi luar menurun (38.8\%). Butir pernyataan ada keterbatasan waktu untuk mengkonseling klien dengan benar tentang versi luar dalam praktik sehari-hari, responden yang setuju mencapai $63.9 \%$. Untuk kerja sama di wilayah praktek yang menghalangi dalam melakukan versi luar, 59.7\% responden menyatakan tidak setuju.

\section{Efikasi Diri}

Untuk dimensi efikasi diri, $77.8 \%$ responden merasa mampu untuk memberikan konseling versi luar kepada semua klien, $70.8 \%$ responden mampu untuk menjelaskan keamanan versi luar, sedangkan hanya $66.6 \%$ responden yang merasa mampu menjelaskan bahwa versi luar merupakan pilihan terbaik dan merasa mampu untuk membuat semua klien memilih versi luar sebagai manajemen presentasi bokong.

\section{Kepatuhan terhadap Aspek-aspek Pelaksanaan Versi Luar}

Aspek konseling versi luar, $70.8 \%$ responden menjawab tidak ada sampai sebagian kecil klien yang diberikan konseling tentang versi luar, sedangkan yang menjawab sebagian besar sampai semuanya hanya $20.8 \%$ responden. Untuk aspek meyakinkan klien tentang keunggulan versi luar, $81.9 \%$ responden menjawab tidak ada sampai dengan sebagian kecil klien yang diyakinkan tentang versi luar. Hanya $15.3 \%$ responden yang meyakinkan sebagian besar sampai dengan semua klien tentang keunggulan versi luar. Untuk aspek upaya versi luar (baik melakukan sendiri atau merujuk kepada yang lebih ahli), hanya $16.6 \%$ responden yang mengupayakan versi luar pada sebagian besar sampai semua klien. Sebesar $81.9 \%$ responden menyatakan tidak ada sampai dengan sebagian kecil klien yang diupayakan versi luar.

\section{Faktor yang Mendukung}

Lebih dari 90\% responden setuju bahwa pengetahuan terhadap panduan (guideline) versi luar meningkatkan konseling versi luar, para spesialis obstetri dan ginekologi bertugas memutuskan kontraindikasi versi luar, dan konseling sebaiknya berisi semua informasi tentang persalinan presentasi bokong: mencakup persalinan secara vaginal dan bedah sesar.

Sebagian besar responden (83\%-86\%) setuju dengan pernyataan: Jika perujuk mempunyai persepsi yang lebih baik tentang keahlian dan tingkat 
keberhasilan para spesialis obsgin, lebih banyak wanita dirujuk untuk versi luar dan pencatatan kasus-kasus versi luar pada database obstetri nasional diperlukan untuk evaluasi yang baik.

Sebanyak $76 \%-79 \%$ responden setuju dengan pernyataan: setiap klien dengan presentasi bokong sebaiknya diberikan konseling tentang versi luar, versi luar merupakan terapi yang baik untuk menurunkan angka bedah sesar karena presentasi bokong dan pengalaman klinis profesional mengarah kepada keputusan untuk menawarkan versi luar kepada klien. Lebih dari tiga perempat Dokter SpOG merasa mampu untuk memberikan konseling tentang versi luar.

\section{Faktor yang Menghambat}

Hanya dua pertiga responden yang merasa mampu untuk menjelaskan kepada klien bahwa versi luar merupakan pilihan terbaik dan untuk membuat semua klien memilih versi luar sebagai manajemen presentasi bokong. Kurang dari sepertiga responden setuju dengan pernyataan: selama konseling harus dijelaskan bahwa versi luar merupakan pilihan terbaik untuk klien, para bidan yang terlatih khusus bertugas memutuskan kontraindikasi versi luar dan setiap klien dengan presentasi bokong sebaiknya menjalani versi luar.

Hanya dua pertiga sampai setengah responden yang menyetujui pernyataan: saya bertanggung jawab mendiskusikan alasan jika ada teman sejawat yang tidak menawarkan versi luar; saya bertanggung jawab untuk meyakinkan setiap klien untuk memilih versi luar; para klien lebih puas jika versi luar selalu ditawarkan; dan setiap klien yang gagal versi luar sebaiknya ditawarkan upaya yang kedua.

\section{Korelasi antara Dimensi Kuesioner dengan Luaran Perilaku Versi Luar}

Luaran konseling berhubungan sedang dengan dimensi sikap terhadap versi luar $(r=0.449, p=$ $0.000)$, orientasi tugas $(r=0.343, p=0.003)$, hasil yang diharapkan $(r=0.380, p=0.001)$ dan efikasi diri $(r=$ $0.489, p=0.000$ ). Tidak ada hubungan antara luaran konseling dengan dimensi prasyarat keberhasilan versi luar ( $r=0.128, p=0.285)$.

Untuk luaran meyakinkan berhubungan kuat dengan dimensi efikasi diri $(r=0.514, p=0.000)$, berhubungan sedang dengan dimensi sikap terhadap versi luar $(r=0.478, p=0.000)$, orientasi tugas $(r=0.256, p=0.030)$, dan hasil yang diharapkan $(r=0.338, p=0.040)$. Luaran ini tidak berhubungan dengan dimensi prasyarat keberhasilan versi luar ( $r=$ 0.138, $p=0.097)$.

Untuk luaran mengupayakan versi luar (mandiri atau merujuk) berhubungan sedang dengan dimensi sikap terhadap versi luar $(r=0.452, p=$ $0.000)$ dan dimensi efikasi diri $(r=0.479, p=0.000)$. Luaran ini berhubungan lemah dengan dimensi hasil yang diharapkan $(r=0.272, p=0.021)$ dan tidak berhubungan dengan dimensi prasyarat keberhasilan versi luar $(r=0.097, p=0.415)$.

\section{Hasil Wawancara Mendalam}

Terdapat beberapa determinan yang mempengaruhi Dokter SpOG dalam melakukan atau tidak melakukan versi luar, antara lain: Keterampilan dalam melakukan versi luar; Pengalaman buruk sebelumnya akibat komplikasi versi luar; Fasilitas jika terjadi komplikasi yang mengancam bayi; Ketersediaan panduan (guideline) versi luar dari POGI; Karakteristik tindakan versi luar; Pembiayaan tindakan versi luar; Pilihan manajemen persalinan presbo selain versi luar; Persepsi versi luar bisa menurunkan angka seksio sesarea; Risiko tindakan versi luar; Pertimbangan pilihan pasien.

\section{Pembahasan}

Hasil penelitian ini menunjukkan terdapat berbagai macam faktor pendukung dan faktor penghambat dilakukannya versi luar. Data kuantitatif menunjukkan sebagian besar Dokter SpOG setuju dengan pernyataan bahwa setiap klien dengan presentasi bokong sebaiknya diberikan konseling tentang versi luar dan versi luar merupakan terapi yang baik untuk menurunkan angka bedah sesar karena presentasi bokong. Meskipun demikian, hanya kurang dari separuh responden yang merasa bertanggung jawab untuk meyakinkan semua klien untuk memilih versi luar. Hal yang mengejutkan dari faktor sikap ini adalah persetujuan dari responden yang sangat rendah pada butir versi luar merupakan pilihan terbaik untuk klien dan setiap klien dengan presentasi bokong sebaiknya menjalani versi luar.

Ada beberapa penjelasan yang mungkin dari hasil yang bertentangan ini. Pertama, adanya 
pandangan bahwa pada presentasi bokong mode persalinan yang baik adalah dengan seksio sesarea. Penelitian Term Birth Trial menunjukkan luaran neonatal jangka pendek yang lebih baik pada persalinan dengan seksio sesarea terencana dibandingkan dengan persalinan bokong vagina. ${ }^{1}$ Hasil penelitian ini mungkin mengubah cara pandang Dokter SpOG sehingga lebih memilih seksio sesarea.

Kedua, konseling tentang versi luar juga mencakup kontraindikasi dan risiko yang mungkin terjadi dalam tindakan tersebut. Walaupun persentase terjadinya kecil, versi luar dapat menimbulkan komplikasi yang dapat mengancam keselamatan ibu dan janinnya. ${ }^{5} \mathrm{Hal}$ ini bisa menjadi kekhawatiran dari klinisi untuk menawarkan versi luar kepada klien. Ketiga, jika komplikasi yang berat terjadi harus dilakukan seksio sesarea segera untuk menyelamatkan ibu dan janinnya, hal ini bisa menjadi pertimbangan dari klinisi karena tidak setiap fasilitas kesehatan bisa untuk melakukan seksio sesarea darurat.

Keempat, halini bisa terkait dengan keterampilan yang didapat selama pendidikan residensi. Data lain dari penelitian ini menunjukkan sebagian besar Dokter SpOG menjawab tidak dibekali keterampilan yang memadai dalam melakukan tindakan versi luar selama pendidikan residensi. Hal ini didukung oleh wawancara mendalam yang dilakukan terhadap Dokter SpOG yang tidak melakukan versi luar, yang menyatakan keterampilan yang kurang merupakan determinan utama untuk tidak melakukan versi luar.

Pada dimensi sikap, lebih dari tiga perempat Dokter SpOG setuju bahwa pengalaman klinis profesional mengarah pada keputusan untuk menawarkan versi luar kepada klien. Hal ini menunjukkan pentingnya faktor pengalaman (dalam praktek maupun dalam pendidikan residensi) dalam menawarkan pilihan versi luar kepada klien. Penelitian ini juga menunjukkan, hanya sebagian kecil Dokter SpOG yang pernah melakukan dan percaya diri dalam melakukan versi luar.

Hampir tiga perempat Dokter SpOG menyatakan tidak dibekali keterampilan yang cukup dalam melakukan versi luar selama residensi. Tidak dibekalinya residen keterampilan yang memadai dalam melakukan versi luar mempengaruhi keputusan dalam menawarkan dan mengupayakan versi luar terhadap klien. Hal ini didukung oleh hasil wawancara mendalam yang dilakukan menunjukkan salah satu yang membuat Dokter SpOG tidak melakukan versi luar adalah faktor pengetahuan dan keterampilan yang kurang dalam melakukan prosedur versi luar sehingga berpengaruh terhadap kepercayaan diri (self-efficacy) dalam memberikan konseling, menawarkan dan melakukan versi luar.

Penelitian ini menunjukkan kurang dari 20 persen Dokter SpOG yang memberikan konseling, meyakinkan klien, dan mengupayakan (mandiri atau merujuk) versi luar pada sebagian besar sampai seluruh klien dengan presentasi bokong. Ada beberapa penyebab dari rendahnya kepatuhan ini. Hasil penelitian ini pada aspek kepatuhan terhadap panduan (guidelines) sangat bertolak belakang dengan hasil penelitian di Belanda yang menunjukkan lebih dari 70 persen responden yang memberikan konseling, meyakinkan klien dan mengupayakan versi luar. ${ }^{11}$

Perbedaan ini mungkin disebabkan oleh adanya kebijakan yang jelas dari organisasi profesi di Belanda, yang memang merekomendasikan versi luar sebagai manajemen kehamilan dengan presentasi bokong dalam panduan klinis dari The Dutch Society for Obstetrics and Gynaecology (NVOG). Untuk saat ini sendiri, belum ada panduan klinis tentang versi luar yang dikeluarkan oleh Perkumpulan Dokter Obstetri dan Ginekologi Indonesia (POGI).

Hasil penelitian ini menunjukkan sikap terhadap versi luar (attitude toward ECV) dan keyakinan diri (self-efficacy) yang mempunyai hubungan sedang/ kuat dan bermakna secara signifikan dengan ketiga indikator memberikan konseling, meyakinkan dan melakukan versi luar. Hasil penelitian lainnya yang sejenis di Belanda juga menemukan bahwa sikap terhadap versi luar (attitude toward ECV) dan keyakinan diri (self-efficacy) mempunyai hubungan yang positif dengan kepatuhan terhadap panduan. Hasil dari kedua penelitian ini menunjukkan bahwa kepatuhan terhadap panduan versi luar dipengaruhi oleh keyakinan diri (self-efficacy) dan sikap terhadap versi luar (attitude toward ECV).14 Hasil penelitian lainnya yang menilai kepatuhan klinisi terhadap panduan subfertilitas juga menemukan bahwa keyakinan diri (self-efficacy) merupakan faktor pendukung (facilitator) dan penghambat (barrier) 
yang paling signifikan dalam menentukan kepatuhan terhadap panduan. ${ }^{15}$

Keunggulan penelitian ini adalah merupakan satu-satunya penelitian di Indonesia yang menganalisis versi luar dari sudut pandang Dokter SpOG. Rancangan penelitian yang digunakan juga sangat baik, dengan metode campuran (mixedmethod) yang memperkaya dan memperkuat data dan analisisnya. Selain itu, tema yang diangkat juga salah satu tema yang sesuai dengan panduan WHO untuk menurunkan angka seksio sesarea, yaitu dengan penerapan versi luar pada klien-klien yang memenuhi syarat (eligible).

\section{KESIMPULAN DAN SARAN}

Sebagian besar responden setuju bahwa versi luar merupakan tindakan yang sesuai untuk menurunkan angka seksio sesarea karena presentasi bokong dan melakukan versi luar meningkatkan jumlah presentasi kepala saat persalinan. Namun hanya kurang dari sepertiga responden setuju bahwa selama konseling harus dijelaskan bahwa versi luar merupakan pilihan terbaik untuk klien dan setiap klien dengan presentasi bokong sebaiknya menjalani versi luar. Tingkat kepatuhan dalam aspek pelaksanaan versi luar yaitu: mengkonseling, meyakinkan dan mengupayakan versi luar untuk klien dengan kehamilan presentasi bokong masih sangat rendah. Efikasi diri merupakan determinan paling penting yang mempengaruhi pilihan melakukan versi luar. Terdapat beberapa determinan dari Dokter SpOG dalam keputusan melakukan/ tidak melakukan versi luar.

\section{DAFTAR PUSTAKA}

1. Hannah ME, Hannah WJ, Hewson SA, Hodnett ED, Saigal S, Willan AR. Planned caesarean section versus planned vaginal birth for breech presentation at term: a randomised multicentre trial. Lancet. 2000; 356(9239): 1375-1383. doi: 10.1016/S01406736(00)02840-3

2. Carayol M, Foidart J, Alexander S, Uzan S, Subtil D. Is planned vaginal delivery for breech presentation at term still an option ? Results of an observational prospective survey in France and Belgium Franc. AJOG. 2006;194:1002-1011. doi:10.1016/j.ajog.2005.10.817
3. Caughey AB, Cahill AG, Guise J-M, Rouse DJ. OBSTETRIC CARE CONSENSUS: Safe Prevention of the Primary Cesarean Delivery. Am Coll Obstet Gynecol. 2016;(3):1-19.

4. Royal College of Obstetricians and gynecologist. External cephalic version and reducing the incidence of breech presentation. R Coll Obstet Gynaecol. 2010;(20):1-8.

5. Royal College of Obstetricians and Gynaecologists. Management of Breech Presentation. BJOG. 2017;(20). doi: 10.1111/1471-0528.14465

6. Committe on Obstetric Practice. Committee Opinion: Mode of Term Singleton Breech Delivery. ACOG. 2006; (3): 6-8

7. Kotaska A, Menticoglou S, Gagnon R. Vaginal Delivery of Breech Presentation. JOGC. 2009;(226):557-566.

8. The Royal Australian and New Zealand College of Obstetricians and Gynecologists. Management of breech presentation at term. 2016;(July):1-14.

9. Reichenbach L, Yuan J, Herrmann E, Louwen F. Delivery mode and neonatal outcome after a trial of external cephalic version ( ECV ): a prospective trial of vaginal breech versus cephalic delivery. Arch Gynecol Obs. 2013;287:663-668. doi:10.1007/ s00404-012-2639-1

10. Hofmeyr G., Kulier R, West H. External cephalic version for breech presentation at term (Review). Cochrane Libr. 2016;(4). doi: 10.1002 /14651858. CD000083 .pub3. www.cochranelibrary.com

11. Rosman ANA, Vlemmix FF, Fleuren MAHM, et al. Patients and professionals barriers and facilitators to external cephalic version for breech presentation at term, a qualitative analysis in the Netherlands. Midwifery. 2014;30(3):324-330. doi: 10.1016/j. midw. 2013.03.013

12. Yogev Y, Horowitz E, Ben-Horoush B, Chen R, Kaplan B. Changing Attitudes Toward Mode of Delivery and External Cephalic Version in Breech Presentation. Obstet Gynecol Surv. 2003;58(7):438-455.

13. Vlemmix F, Rosman AN, Fleuren $M A H$, et al. Implementation of the external cephalic version in breech delivery. Dutch national implementation study of external cephalic version. 2010.

14. Rosman AN, Vlemmix F, Beuckens A, et al. Facilitators and barriers to external cephalic version for breech presentation at term among health care providers in the Netherlands: A quantitative analysis. Midwifery. 2014;30(3):e145-e150. doi: 10.1016/j. midw.2014.01.002

15. Haagen EC, Nelen WL., Hermens RPM., Braat DD., Grol RPT., Kremer JA. Barriers to physician adherence to a subfertility guideline. Hum Reprod. 2005;20(12):33013306. doi: 10.1093 /humrep/dei220 